\title{
A Study on the Diversified College English Teaching Mode Based on Artificial Intelligence
}

\author{
Aihua L iu ${ }^{1}$, Dehua Kong ${ }^{2, *}$ \\ ${ }^{1}$ School of Foreign Language and Literature, Wuhan Donghu University, Wuhan, China \\ ${ }^{2}$ School of Computer Science, Wuhan Donghu University, Wuhan, China
}

\begin{abstract}
In recent years, with the widespread application of artificial intelligence, how to apply AI technology to college English teaching is a new challenge in the college English teaching. According to the requirements of "classified guidance and teaching of students according to their abilities" in college English teaching, this article analyzes the integration of artificial intelligence and college English teaching, and tries to explore a personalized, differentiated and diversified university in the context of artificial intelligence. Through teaching practice and designing multiple intelligent English teaching activities, constructing a new college English teaching mode is a new way to reform college English teaching.
\end{abstract}

\section{Introduction}

Professor Howard Gardner, a famous American developmental psychologist and educator, divides human intelligence into eight categories: Linguistic Intelligence, Logical-Mathematical Intelligence, and Visual-Spatial Intelligence, Bodily-Kinesthetic Intelligence, Music Intelligence, Interpersonal Intelligence, Intra-personal Intelligence, and Natural Intelligence, It is the famous "Multiple Intelligence". The theory of multiple intelligences believes that human intelligence is multiple. This is a brand-new cognitive theory that poses a severe challenge to the traditional theory of intelligence. Since the $1980 \mathrm{~s}$, the theory of multiple intelligences has been actively applied to the field of education, and a series of education and teaching reforms have been carried out based on the theory of multiple intelligences. Multiple intelligences have brought new enlightenment to educators and education managers, and at the same time they have played an active guiding role in education reform. The author integrates the theory of multiple intelligences into college English teaching, adopts the methods of investigation and research, and demonstrates a new mode of multiple intelligences college English teaching through the three steps of questionnaire survey, classroom practice, and summary reflection.

\section{Multiple Intelligence Theory}

The Theory of Multiple Intelligences, referred to as MI theory, was proposed in 1985 by Howard Gardner, a psychologist at Harvard University in the United States, in the book The Structure of Intelligence. Gardner believes that human intelligence is diverse, mainly including eight types: Linguistic Intelligence, Logical-
Mathematical Intelligence, and Visual-Spatial Intelligence, Bodily-Kinesthetic Intelligence, Music Intelligence, Interpersonal Intelligence, Intra-personal Intelligence, and Natural Intelligence. These eight types of intelligence are independent and affect each other, but they are not integrated (Gardner, 1993). Through the analysis of Gardner's theory of multiple intelligences, we believe that the main implications of this theory are as follows.

- Each individual's intelligence has its own characteristics and unique manifestations. According to Gardner's theory of multiple intelligences, as an individual, everyone has eight relatively independent intelligences at the same time, and the combination of these eight intelligences in different ways and different degrees in each person makes each person's intelligence unique.

- Intelligence emphasizes the individual's ability to solve practical problems and the ability to produce and create effective products needed by society. According to Gardner's theory of multiple intelligences, intelligence should emphasize two aspects of abilities. One aspect is the ability to solve practical problems, and the other aspect is the ability to produce and create effective products that society needs.

- The theory of multiple intelligences emphasizes the multidimensional approach to intelligence issues. According to Gardner's theory of multiple intelligences, it is recognized that intelligence is composed of multiple abilities that are equally important rather than one or two core abilities, and that various intelligences are manifested in multiple dimensions and relatively independently rather than in an integrated manner. Come out, this is the essence of multiple intelligence theory. 


\section{Integration of Multiple Intelligences Theory and College English Teaching}

The maturity and completeness of the theory of multiple intelligences guarantees its strong basic force in guiding teaching reform. The theory of multiple intelligences emphasizes the multiple functions of teaching multimedia, multiple senses and multiple intelligences, and believes that every student has the potential of eight kinds of intelligence. The goal of the multi-intelligence education view is to improve the comprehensive quality and ability of students, which is consistent with the ultimate goal of language learning. Language reflects its value in application, and it tests the comprehensive ability of language learners in language use. Therefore, the author designed a set of new models suitable for college English teaching based on the theory of multiple intelligences. According to Li Zhiying, the integration of multiple intelligence theory and college English teaching must follow four principles, namely: system design principles, teaching students in accordance with their aptitude, language intelligence [3]. The multiintelligence college English teaching practice carried out by the author runs through these four principles. First, the four semesters of college English will be completed in the course catalogue to be selected and systematically arranged; secondly, according to the different student subjects faced, based on questionnaires Investigate data, teach students in accordance with their aptitude, and adopt different teaching strategies; third, make full use of the students' other advantages in the teaching process to develop language intelligence; fourth, the design of teaching activities is operable, simple and flexible, It is convenient for teachers and students to complete. The design concept of the multi-intelligence college English teaching mode is: personalized college English teaching should conform to and give play to the superior intelligence of students, and care and improve the inferior intelligence of students. The design method is to use a variety of multiple intelligence activities to integrate with the five major English skills, develop diversified teaching methods, and drive each link of English learning with corresponding teaching strategies. The design goal is to increase the participation rate of students in college English classes, enhance the multilateral interaction between teachers and students, students and students, and develop the ability to use English comprehensively. Language acquisition should be omni-directional, multi-channel and individualized. The college English teaching mode designed based on the theory of multiple intelligences can help English educators to further fully understand and develop each student's potential and provide a strong theoretical basis.

\section{Multiple Intelligences College English Teaching Activities}

\subsection{Multiple Intelligence Tests}

In order to ensure the rationality and orderliness of the teaching design, a "multiple intelligence test" was conducted on the four natural classes taught at the beginning of the semester. The students in the four classes come from 4 colleges and 12 different majors. The survey subjects are broad, making the test results more universal, and real-name questionnaire surveys are conducted in order to record the differences in intelligence of students. The test questionnaire is adapted and designed on the basis of the test questions in the Multiple Intelligences Developmental Assessment Scales (MIDAS), a multiple intelligence development assessment system developed by Dr. Branton Shearer. The author designed 80 test questions according to the eight types of multiple intelligences, and each type of intelligence contains 10 test questions. The highest score for each item is 10 points, and the lowest score is 0 points. Multiply the scores of each group by 10 to get the score for each item under the percentile system. Finally, the students' scores of various intelligences are compared horizontally, so as to have an overall understanding of the intelligence tendency of the survey objects. The research group issued 240 test papers and recovered 233 valid answer papers. The test results are shown in the following table:

Table 1. Test results of multiple intelligences of college students

\begin{tabular}{|c|c|c|c|}
\hline Smart type & $\begin{array}{c}\text { Score } \\
80-100\end{array}$ & $\begin{array}{c}\text { Score } \\
60-80\end{array}$ & $\begin{array}{c}\text { Score60 } \\
\text { points or less }\end{array}$ \\
\hline $\begin{array}{c}\text { Linguistic } \\
\text { intelligence }\end{array}$ & 45 & 56 & 321 \\
\hline $\begin{array}{c}\text { Math-Logical } \\
\text { Intelligence }\end{array}$ & 32 & 47 & 154 \\
\hline $\begin{array}{c}\text { Visual spatial } \\
\text { intelligence }\end{array}$ & 26 & 80 & 127 \\
\hline $\begin{array}{c}\text { Bodily- } \\
\text { Kinesthetic } \\
\text { intelligence }\end{array}$ & 78 & 87 & 68 \\
\hline $\begin{array}{c}\text { Music } \\
\text { intelligence }\end{array}$ & 85 & 74 & 74 \\
\hline $\begin{array}{c}\text { Interpersonal } \\
\text { intelligence }\end{array}$ & 66 & 76 & 155 \\
\hline $\begin{array}{c}\text { Natural } \\
\text { observation } \\
\text { intelligence }\end{array}$ & 33 & 51 & 152 \\
\hline $\begin{array}{c}\text { Introspective } \\
\text { intelligence }\end{array}$ & 30 & & \\
\hline
\end{tabular}

The test results show that only $19 \%$ of students have outstanding performance in language intelligence, 36\% of students have excellent performance in music intelligence, and $33 \%$ of students have excellent performance in sports intelligence. For English learning and teaching, the performance of language intelligence directly affects the effect of English learning, especially the output of spoken English. Therefore, as English 
educators, we should make full use of students' respective superior intelligence, and use superior intelligence as a means to mobilize students' enthusiasm for participating in learning, so as to achieve the goal of developing "linguistic intelligence".

\subsection{The Teaching Practice Process of Multiple Intelligences}

The actual application of multiple intelligences to teaching practice will not be effective by just relying on one lesson or one teaching activity. Our goal is to establish a long-term teaching model, and continuously add new elements to this model in teaching practice to make it more vital. The author takes the second semester of 2018-2019 as the first stage of teaching practice, combining the textbook "New Edition College English Comprehensive Course" (Shanghai Foreign Language Education Press, 2010) and "New Vision University English Audiovisual Listening and Speaking" (Foreign Language Teaching and Research Press, 2011) teaching materials serve as the blueprint for the design of teaching activities. Incorporating various multiple intelligence teaching activities into the teaching process, after a semester of practice, the teaching effect has been significantly improved. Now select one of the units as an example, as follows:

- Teaching content: "University English Comprehensive Course 4" Unit One: Fighting with the Forces of Nature. Text A: The Icy Defender.

- Pre-class preparation: Arrange the topic of oral presentation in this unit one week in advance: "Who is more powerful than human beings and nature?" According to the test records of this class's multiple intelligences, divide the whole class into groups and determine that the "Interpersonal Intelligence" performs well As the leader of the group, organize group members to debate; determine that the students with outstanding performance in "natural intelligence" organize the discussion content and make written records; in addition, determine the students with outstanding performance in "linguistic intelligence" as the spokesperson of this group, Present the results of this group discussion in front of the class.

- The first step of classroom teaching: Closely focus on the theme of this unit "Fight against the forces of nature". There are four groups in the class, and each group of speakers has a time limit of 90 seconds. The group's views are expressed in English concisely and concisely.

- The second step of classroom teaching: Read the text quickly for 4 minutes, and sort out the time, sequence, place, and characters of historical events in the text. The teacher disrupted the sequence of events, allowing students with excellent performance in "mathematics-logic intelligence" to reorganize and match the sequence of events. The teacher summarizes and analyzes the structure of the article in the order of events, and the students also complete the "Text Organization" part after class.

- The third step of classroom teaching: Learning the knowledge points of the text language, focusing on "story writing (logical intelligence, language intelligence), description of the picture content displayed by the courseware (visual-spatial intelligence, language intelligence), word expansion solitaire (logic) Smart)" and other classroom activities are integrated with the key language knowledge of this article.

- Consolidation after class: Connect the learning theme of this unit to personal life, write English essays or study reflection (introspective intelligence, language intelligence).

The purpose of college English teaching under the guidance of multiple theories is to scientifically and rigorously design the teaching process, adopt corresponding teaching strategies, and use multiple intelligence teaching activities to complete the goal of developing students' English language intelligence. Under the guidance of the theory of multiple intelligences, the pre-class preparation stage presents a "group cooperative learning" mode, and the process of group discussion and data collection is also a process of "exploratory learning"; in the entire teaching process, the teacher acts as the class organizer Lead the students to discuss and learn English language and culture with the inspirer. After the classroom study is completed, students can complete small essays or study reflections on their own, which is the mode of "self-learning". The new diversified college English teaching model includes autonomous learning, exploratory learning, and cooperative learning and so on. Based on the test results, the author designed Table2, a teaching activity table for multiple intelligences and college English learning. In the process of designing the teaching activity table, we incorporated the five skills of listening, speaking, reading, writing and translation into different intelligent activities according to the classification of the four intelligences. The activity design follows the two principles of diversification of teaching methods and systematic learning of students, taking into account the individual characteristics of each student and the general performance of most students. In the actual teaching process, take the "Multiple Intelligence English Activity Table" as a reference to design each class specifically.

Table2. College English Multiple Intelligences Teaching Activity Design Table

\begin{tabular}{|l|l|l|l|l|}
\hline Smart Type & Teaching Activities & Teaching Aids & Teaching Strategy & $\begin{array}{l}\text { Develop } \\
\text { English Skills }\end{array}$ \\
\hline $\begin{array}{l}\text { Linguistic } \\
\text { intelligence }\end{array}$ & $\begin{array}{l}\text { Group discussions, vocabulary } \\
\text { games, } \\
\text { English stories, Recitation, }\end{array}$ & $\begin{array}{l}\text { English books, CDs, } \\
\text { magnetic } \\
\text { Tape, tape recorder }\end{array}$ & $\begin{array}{l}\text { Read, write, talk, } \\
\text { Listen to the Topic } \\
\text { Content }\end{array}$ & $\begin{array}{l}\text { Listening, } \\
\text { Speaking } \\
\text { Reading and } \\
\text { Writing }\end{array}$ \\
\hline
\end{tabular}




\begin{tabular}{|l|l|l|l|l|}
\hline $\begin{array}{l}\text { Bodily- } \\
\text { Kinesthetic } \\
\text { intelligence }\end{array}$ & $\begin{array}{l}\text { body language, Sign language, } \\
\text { sports activities, Drama } \\
\text { performance }\end{array}$ & $\begin{array}{l}\text { Props, equipment, and } \\
\text { themes } \\
\text { Related appliances }\end{array}$ & $\begin{array}{l}\text { performance, touch, } \\
\text { Show it bravely }\end{array}$ & $\begin{array}{l}\text { Listening, } \\
\text { Speaking, } \\
\text { Reading }\end{array}$ \\
\hline $\begin{array}{l}\text { Interpersonal } \\
\text { intelligence }\end{array}$ & $\begin{array}{l}\text { Group cooperation, peer } \\
\text { coaching, Social surveys, team } \\
\text { activities }\end{array}$ & $\begin{array}{l}\text { Questionnaire, English } \\
\text { corner, } \\
\text { English party }\end{array}$ & $\begin{array}{l}\text { Communication } \\
\text { cooperative learning }\end{array}$ & $\begin{array}{l}\text { Listening, } \\
\text { Speaking } \\
\text { Reading and } \\
\text { Writing }\end{array}$ \\
\hline Music intelligence & English song learning & $\begin{array}{l}\text { Video recorder, tape } \\
\text { recorder, } \\
\text { Special Music }\end{array}$ & $\begin{array}{l}\text { Listen, sing, and } \\
\text { learn the topics } \\
\text { presented }\end{array}$ & $\begin{array}{l}\text { Listening, } \\
\text { Speaking, } \\
\text { Translating }\end{array}$ \\
\hline
\end{tabular}

\subsection{Teaching Effect and Reflection}

After a semester of teaching practice, the teaching effect has been significantly improved: First, students are more confident in the English class. They find their own advantages and the best way to express English, and use this to drive their enthusiasm for learning English in all aspects. Second, teachers are more diligent in thinking. In order to make the classroom design more perfect, the teacher needs to collect a lot of information and materials, including consulting peers, communicating with foreign teachers, self-demonstration and so on. Third, the teaching process has been optimized and the quality of teaching has improved. The well-designed multiintelligence English teaching model has fully mobilized students' interest in learning, and the English classroom has truly achieved the goal of "student-centered" and "let students speak". Students' characteristic abilities are displayed in the English activities designed in the classroom and interact with teaching activities to form a virtuous circle. Although under the new teaching model, both students and teachers have made certain achievements, and also changed the previous teaching situation, there are still some problems. For example: the teaching implementation process does not match the final teaching evaluation, and both students and teachers have scruples. Second, the strength of a teacher alone is too weak to form a joint force, and it lacks the advantage of team combat effectiveness. Coverage is only a few classes taught, and cannot benefit the entire school or the entire region.

\section{Diversified College English Teaching Mode}

The diversified college English teaching mode is exactly the teaching mode that is integrated with the goals of college English teaching. It includes autonomous learning, inquiry learning, and cooperative learning and so on. The scientific integration of these teaching modes forms the core of the diversified college English teaching mode, which provides a scientific guarantee for cultivating and developing students' diversified intelligence and achieving the goals of college English teaching.

\subsection{Autonomous Learning based on computer network technology}

The so-called "autonomous learning" is in terms of the inherent quality of learning, in contrast to "passive learning", "mechanical learning" and "other-directed learning". (Zhong Yan, 2001) From the perspective of educational psychology, students' learning styles can be divided into two types: acceptance and discovery. Acceptance learning is for the purpose of obtaining systematic subject knowledge. The content of learning is presented in the form of conclusions. Students are the receivers of knowledge. Discovery learning is also aimed at the acquisition of systematic subject knowledge, but emphasizes that students actively discover, analyze, understand and master the basic structure in the process of acquiring knowledge. The learning content is often presented in the form of questions. Students are the discoverers of knowledge. The two learning methods, acceptance and discovery, complement each other and constitute the main content of autonomous learning.

\subsection{Inquiring Learning based on humanism}

Humanistic educational thoughts treat students as "complete people" and "exploratory", "creative", "discovery", etc. as organic components of a complete personality. Advocating "inquiry learning" in the diversified teaching model is to respect students' personalities and create space for the full development of their multiple intelligences. Inquiry learning can build an open learning environment for students, provide a multichannel acquisition of knowledge, and the opportunity to integrate and apply the learned knowledge to practice. This learning method has the characteristics of learning, research and experiment. Different from receiving learning, this is a comprehensive learning method centered on problems in practice. Students not only need to learn knowledge about the subject, but also learn some basic research procedures and methods.

When evaluating whether cooperative learning is effective or successful, we need to get rid of the traditional evaluation system that uses scores to measure everything. The evaluation of cooperative learning should be diversified, holistic and procedural. In order to achieve the best results, group cooperative learning should pay attention to: subject participation and group cooperation, independent thinking and cooperative learning, teacher guidance and group activities, classroom discipline and democracy, openness. Dealing 
with this pair of contradictions can ensure effective and successful cooperative learning.

\section{Conclusion}

The teaching concept of multiple intelligence theory coincides with the teaching requirement of "College English teaching should implement the principles of classified guidance and teaching students in accordance with their aptitude to meet the actual needs of individualized teaching" proposed in "College English Course Teaching Requirements". Combine different types of multiple intelligences with corresponding teaching strategies to cultivate and improve students' five skills in English learning. In addition, college English teaching should also cooperate with the development of other intelligences to provide a foundation for the integration of knowledge and ability development in various disciplines. Gardner's theory of multiple intelligences provides us with a useful reference for changing our educational concepts and for us to build an education and teaching mode that adapts to the spirit of the 21 st century. The emergence of diversified college English teaching modes has injected new vitality into the reform of college English teaching. Its application and practice will definitely help to change the single situation of college English teaching models and evaluation systems, so as to realize the change from teachercentered The transformation from a teaching model that simply imparts language knowledge and skills to a student-centered teaching model that not only imparts general language knowledge and skills, but also focuses on cultivating students' multiple intelligences.

\section{ACKNOWLEDGMENTS}

This article is supported by the Youth Fund Project of Wuhan Donghu Academy of Sciences in 2019, "Research on Product Recommendation Based on Web Space-Time Customer Behavior Trajectory" < No: 2019dhzk006>.

\section{References}

1. Harvard Gardner. (1983) The Theory of Multiple Intelligence. New York: Basic Books.

2. Luo Zhongmin.(2003) MI Theory and Its Significance in Foreign Language Teaching. Foreign Languages, 6:122-126.

3. Li Zhiying.(2002) A Preliminary Study on the Integration of Multiple Intelligences Theory and English Teaching . Foreign Language Audiovisual Teaching, 10:68-71.

4. Liang Aimin.(2006) Research on Multiple Intelligence Theory and Multiple College English Teaching Models. Shandong Foreign Language Teaching, 5:92-95.

5. Li Xi. (2016) Constructing a New Mode of College English Teaching under the Theory of Multiple
Intelligences. Journal of Hunan University of Science and Technology, 3: 157-158.

6. Kang Yue.(2007) The Application of Multiple Intelligences Theory in College English Network Multimedia Teaching. Foreign Language Teaching, 7: 181-182.

7. Shen Caifen, Cheng Dongyuan.(2004) Multiple Intelligence Theory and Foreign Language Teaching $[\mathrm{J}]$. Journal of PLA University of Foreign Languages, 4: 36-38.

8. Cheng Weijuan, Li Xiaorong.(2020) Research on College English Vocabulary Online Teaching Based on Multiple Intelligence Theory. Heike Academic Journal, 6: 105-106. 